\title{
Ligand Exchange Processes on Solvated Zinc Cations. DFT Analysis of Hydrogen Cyanide Exchange on [Zn(HCN)6]2+
}

\begin{tabular}{|c|c|}
\hline Journal: & Zeitschrift für Anorganische und Allgemeine Chemie \\
\hline Manuscript ID: & zaac. 200900160.R1 \\
\hline Wiley - Manuscript type: & Article \\
\hline $\begin{array}{l}\text { Date Submitted by the } \\
\text { Author: }\end{array}$ & 14-May-2009 \\
\hline Complete List of Authors: & $\begin{array}{l}\text { Puchta, Ralph; Institute for Inorganic Chemistry, University of } \\
\text { Erlangen-Nürnberg } \\
\text { van Eldik, Rudi; Inorganic Chemistry, Department of Chemistry and } \\
\text { Pharmacy } \\
\text { Alzoubi, Basam M.; Department of Basic Science }\end{array}$ \\
\hline Keywords: & $\begin{array}{l}\text { HCN exchange, Density functional calculations, Zinc, Coordination } \\
\text { chemistry }\end{array}$ \\
\hline
\end{tabular}

\section{s ScholarONE" \\ Manuscript Central}


Sehr geehrter Herr Prof. Jansen,

anbei finden sie unser überarbeitetes Manuskript zaac.200900160 ("Ligand Exchange Processes on Solvated Zinc Cations. DFT Analysis of Hydrogen Cyanide Exchange on $[\mathrm{Zn}(\mathrm{HCN}) 6] 2+")$ und unsere Antworten auf die Anmerkungen der Gutachter.

Wir hoffen, dass unser Manuskript in der jetzigen Form geeignet ist für ZAAC.

Mit freundlichen Grüßen

Ralph Puchta

Reviewer: 1

Comments to the Author

This is sound but exclusively affirmative theoretical work. It is an editorial decision whether such results are compatible with the profile of ZAAC.

The authors make repeatedly clear that the results are just supportive, confirming "once again" the character of $\mathrm{HCN}$ as water-like, the mechanistic preference as with other metal ions, the role of charge and size.

I consider the work acceptable if the parts dealing with those trivial aspects are significantly condensed, and if more interesting aspects e.g. on $\mathrm{H}$ bonding or on $\mathrm{Zn}$ coordination ambivalence are being discussed.

We shortened the aspect of $\mathrm{HCN}$ as a water-like solvent and focused more on H-bonding, as suggested. Parallel we stressed our original intention more to correct the wrong published mechanism. With respect to Prof. Wasada-Tsutsui we did not point this out so directly before, but with the Reviewer 1's encouragement we added a few sentences.

The reference choice in the introduction is curious; organozinc compounds cannot be seriously considerd as models. Instead, Vahrenkamp's or RJP Williams' characterisation of $\mathrm{Zn}(2+)$ is recommended for citation. 
Personally we are a little bit surprised, that Reviewer 1 detected organozinc compounds in our literature. Since we assume that Reviewer 1 relies on Lit [8] (Z. Rappoport, I. Marek, The Chemistry of Organozinc Compounds) and other readers could get the same impression, we extended the citation to:

[1] G. Schürer, T. Clark, R. van Eldik "The reaction mechanisms of zinc enzymes” in Z. Rappoport, I. Marek, The Chemistry of Organozinc Compounds, Chap. 1, Part 1, John Wiley \& Sons Ltd, England, (2006).

We totally agree that the work by Vahrenkamp and RJP Williams has to be cited, and we have corrected this.

Reviewer: 2

Comments to the Author

The authors study the ligand exchange mechanism in $[\mathrm{Zn}(\mathrm{HCN}) 6] 2+$ by DFT methods. All the structures and energies have been evaluated in the gas phase.

\section{Major concerns:}

1. Although the authors allegedly aim at studying the processes that metal cations undergo in solutions, they have limited themselves to the gas-phase calculations only. The complexes are highly charged (overall charge +2 ) and the solvation effects, especially in such high dielectric medium as liquid $\mathrm{HCN}$, are expected to be quite substantial and may alter the gas-phase reaction pathway. Therefore, the authors should evaluate thermodynamic parameters for the respective reactions in the condensed media before making definitive conclusions about the reaction mechanism.

The appropriate consideration of solvent effects is still a challenging task. On the one hand there are very crude implicit solvent models, but on the other hand one can apply $a b$ initio molecular dynamic simulations. While the latter give good and reliable results, they are very expensive/computer time consuming. The implicit solvent models like CPCM, IPCM etc. are fast and easily available, but very crude and tend to collapse in many 
cases. As we did not want to bore our readers with too much detail, we did not mention in the submitted document that we tried to evaluate all stationary points at least by single point calculations with such implicit solvent models. Sadly, one calculation failed. As expected from earlier similar studies, the parts of the presented reactions that we could evaluate did not show any significant difference from the presented (gas phase) data.

2. Entropic effects are not expected to be negligible either and should be taken into account too. Thus, free energies, instead of reaction energies should be evaluated.

We did not calculate entropic contributions for the following reasons: Entropic effects are hardly manageable in such reactions. The entering solvent comes from the bulk and the leaving solvent again goes to the bulk. Therefore fair equations that will lead to comparable results are a problem. As in a related study (ChemPhysChem 2007, 8, 1315 1320) we inspected this question for free energies and did not find significant improvements, and to obtain comparable results with former studies we applied the concept of M. Hartmann, T. Clark, R. van Eldik, J. Am. Chem. Soc. 1997, 119, 5867. We are convinced that only ab initio molecular dynamic simulations offer the chance to consider entropic and solvent effects in a reasonable way. For this and the above mentioned reasons we plan to extend our studies in the direction of $a b$ initio molecular dynamic simulations, but this is a question of available resources.

\section{Minor issues:}

It is not quite clear to the reader what the purpose/motivation/usefulness of this study is. It will be beneficiary for the paper if the authors could elaborate more on this issue and outline the significance of their findings.

We improved this as described in the response to Reviewer 1. 


\section{Synopsis}

\section{Ligand Exchange Processes on Solvated Zinc Cations.}

DFT Analysis of Hydrogen Cyanide Exchange on $\left[\mathrm{Zn}(\mathrm{HCN})_{6}\right]^{2+}$

Basam M. Alzoubi, Ralph Puchta* and Rudi van Eldik*

Possible mechanisms for hydrogen cyanide exchange on $\left[\mathrm{Zn}(\mathrm{HCN})_{6}\right]^{2+}$ were studied using density functional theory (B3LYP/6-311+G**). The computed structural parameters and activation energies show that the activation barrier for a limiting dissociative (D) mechanism ( $7 \mathrm{kcal} \mathrm{mol}^{-1}$ ) is clearly more favorable than for an associative interchange $\left(I_{a}\right)$ mechanism $\left(15.9 \mathrm{kcal} \mathrm{mol}^{-1}\right)$. HCN exchange exhibits a limiting dissociative mechanism similar to that found for water exchange on $\left[\mathrm{Zn}\left(\mathrm{H}_{2} \mathrm{O}\right)_{6}\right]^{2+}$. The results support the classification of $\mathrm{HCN}$ as a water-like solvent.

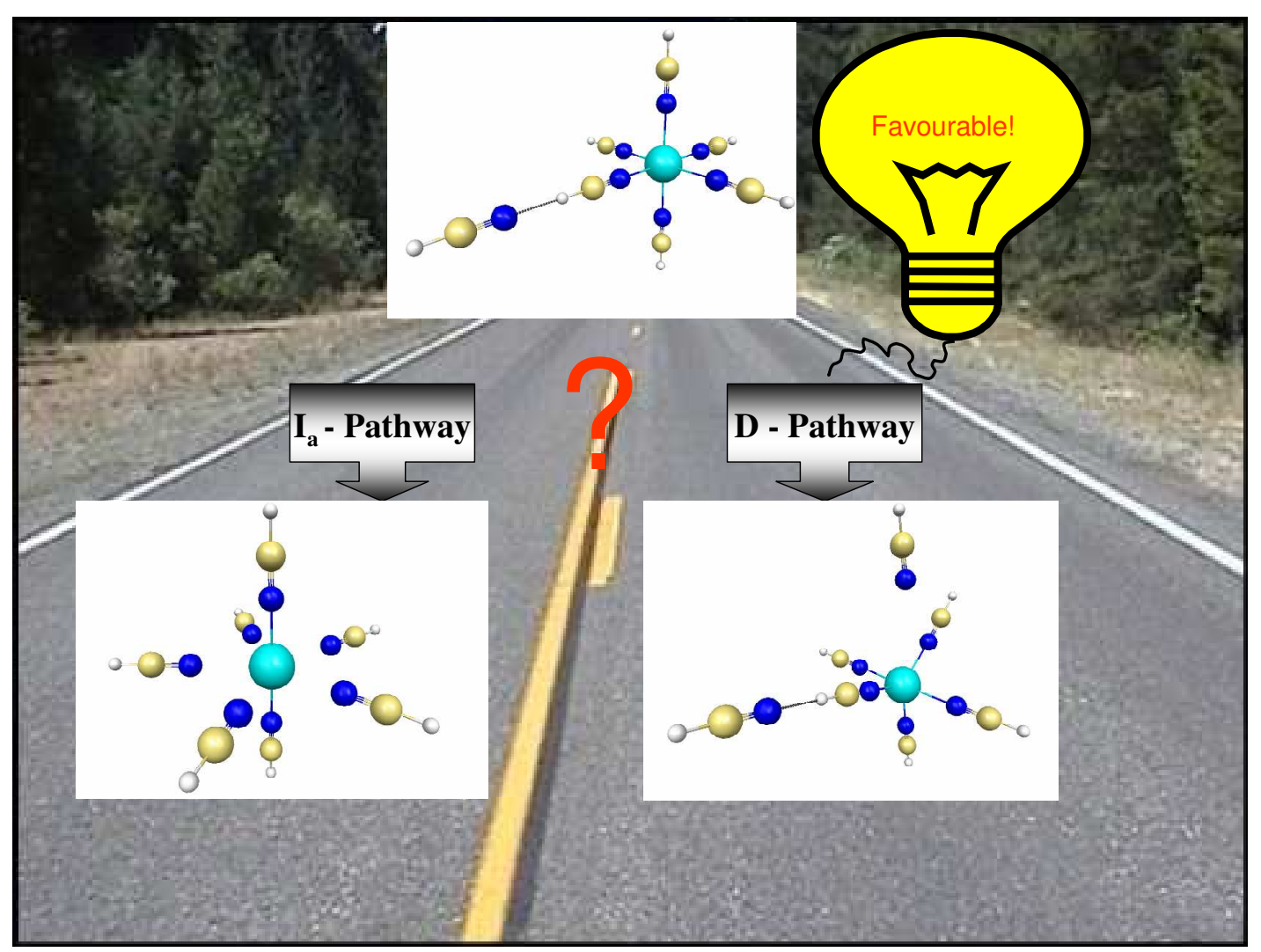




\title{
Ligand Exchange Processes on Solvated Zinc Cations - DFT Analysis of Hydrogen Cyanide Exchange on $\left[\mathrm{Zn}(\mathrm{HCN})_{6}\right]^{2+}$
}

\author{
Basam M. Alzoubi, ${ }^{\mathrm{a}, \mathrm{b}}$ Ralph Puchta, ${ }^{\mathrm{a}, \mathrm{c} *}$ and Rudi van Eldik ${ }^{\mathrm{a} *}$ \\ Dedicated to Professor Lutz Dahlenburg on the Occasion of his 65th Birthday
}

\begin{abstract}
Keywords:
HCN exchange; Density functional calculations; Zinc; Coordination chemistry
\end{abstract}

\begin{abstract}
:
The mechanisms for hydrogen cyanide exchange on $\left[\mathrm{Zn}(\mathrm{HCN})_{6}\right]^{2+}$ were studied using density functional theory (B3LYP/6-311+G**), and showed that the limiting dissociative (D) pathway is more favorable than the associative interchange $\left(I_{a}\right)$ mechanism. The activation barrier for the dissociative mechanism $\left(7 \mathrm{kcal} \mathrm{mol}^{-1}\right)$ is clearly lower than for the interchange mechanism $\left(15.9 \mathrm{kcal} \mathrm{mol}^{-1}\right)$.
\end{abstract}

\footnotetext{
${ }^{a}$ Inorganic Chemistry, Department of Chemistry and Pharmacy, University of ErlangenNürnberg, Egerlandstr. 1, 91058 Erlangen, Germany

${ }^{\mathrm{b}}$ Department of Basic Science, Zarka University College, Al-Balqa Applied University, Zarka, Jordan

${ }^{\mathrm{c} C}$ Computer Chemistry Center, Department of Chemistry and Pharmacy, University of Erlangen-Nürnberg, Nägelsbachstr. 25, 91052 Erlangen, Germany

E-mails: Ralph.Puchta@chemie.uni-erlangen.de and Rudi.vanEldik@chemie.unierlangen.de
} 


\section{Introduction:}

Zinc is the second most abundant transition metal in living organisms and plays a very important role in structural and reactive biochemical processes, viz. it is involved in nucleic acid binding and gene regulation [1]. It shows six-fold coordination with small solvent molecules like water or acetonitrile [2]. In zinc-finger proteins and enzymes, zinc is usually tetrahedrally coordinated, but in some catalytic binding sites it is found to be five-coordinate and rather rarely as six-coordinate [3]. Divalent zinc coordinates to hard and soft ligands present in metalloenzymes due to its flexible coordination geometry, lack of redox activity, intermediate polarizability, and being on the borderline of the hard-soft character [4]. In the case of model complexes, it can form four-,[5] five-,[6] and sixcoordinate[7] complexes, which is dictated by the ligand size, structure and charge [8].

Water exchange reactions, or solvent exchange reactions in a more general sense, are the most fundamental substitution processes that a metal ion in solution can undergo. There are three simple mechanistic pathways for solvent exchange: (i) the limiting dissociative (D) process with an intermediate of lower coordination number; (ii) the limiting associative (A) process with an intermediate of higher coordination number; (iii) the interchange (I) process, in which no intermediate is involved and the exchange occurs in a concerted manner. The interchange process can be more dissociative $\left(I_{d}\right)$ or more associative $\left(I_{a}\right)$ in nature, depending on whether bond breakage or bond formation is more important, respectively. For the interchange mechanisms, the reactants have been suggested to form a precursor-complex prior to the rate-determining interchange step [9]. The present understanding of solvent exchange mechanisms is largely based on volume of activation $\left(\Delta V^{\ddagger}\right)$ data measured for such processes [10]. For this purpose much development has gone into high-pressure NMR techniques in order to determine exchange rate constants as a function of pressure up to $300 \mathrm{MPa}$ [11].

The water exchange mechanism of hydrated zinc(II) was studied theoretically by Hartmann et al. [12,13] Structures and hydration energies were calculated using hybrid density functional theory (DFT) for $\left[\mathrm{Zn}\left(\mathrm{H}_{2} \mathrm{O}\right)_{n}\right]^{2+}$ with $n=1-6$ and for 
$\left[\mathrm{Zn}\left(\mathrm{H}_{2} \mathrm{O}\right)_{\mathrm{n}} \cdot m \mathrm{H}_{2} \mathrm{O}\right]^{2+}$ where $n=5, m=1,2 ; \mathrm{n}=6, m=1$; and $n=3-6, m=0-2$ where $\mathrm{n}$ and $m$ represent the number of water molecules in the coordination and solvation spheres, respectively. On the basis of structures and energies, the water exchange mechanism for $\left[\mathrm{Zn}\left(\mathrm{H}_{2} \mathrm{O}\right)_{6}\right]^{2+}$ was found to be a limiting $\mathrm{D}$ mechanism and the results are in good agreement with ab initio calculations and self-consistent reaction field methods [14]. Beside the work by Hartmann et al., a solvent exchange study by Wasada-Tsutsui et al. [15] suggested for the water like solvent $\mathrm{HCN},[16]$ based on quantum chemical calculations, an associative $\mathrm{HCN}$ exchange at $\left[\mathrm{Zn}(\mathrm{HCN})_{6}\right]^{2+}$ without providing any mechanistic details.

Recently, we showed on the basis of quantum chemical calculations that water and HCN exchange on $\left[\mathrm{Li}(\mathrm{S})_{4}\right]^{+},[17,18]\left[\mathrm{Be}(\mathrm{S})_{4}\right]^{2+}[19]$ and $\left[\mathrm{Al}(\mathrm{S})_{6}\right]^{3+}[20,21]\left(\mathrm{S}=\mathrm{H}_{2} \mathrm{O}, \mathrm{HCN}\right)$ show the same type of mechanism. The exchange mechanism for solvated $\mathrm{Li}^{+}$is of the limiting associative (A) type, for solvated $\mathrm{Be}^{2+}$ of the interchange (I) type, and solvated $\mathrm{Al}^{3+}$ follows a limiting dissociative (D) mechanism. Based on this analogy between the water and hydrogen cyanide exchange mechanisms, we expect on the basis of Hartmann's work a dissociative solvent exchange process for $\mathrm{Zn}^{2+}$ in contrast to the finding of Wasada-Tsutsui et al. [15]. This aspect has therefore been studied in more detail in the present study.

\section{Quantum chemical methods}

Following the suggestions of Hartmann et al.,[13] and for comparison with recent studies on solvent exchange at $\mathrm{Li}^{+},[17,18,22] \mathrm{Be}^{2+},[19,23]$ and $\mathrm{Al}^{3+},[20,21]$ we fully optimized the structures at the B3LYP/6-311+G** level of theory[24] and characterized by computation of vibration frequencies the structures as local minima or transition states. The Gaussian 03 suite of programs was used throughout [25].

\section{Results and Discussion}

The reactant, transition and intermediate states were calculated for hydrogen cyanide exchange. The computed data offered two transitions states for limiting dissociative and 
associative interchange exchange mechanisms. In the present work, the two mechanisms were studied in more detail using structural parameters and activation energies to pinpoint the more favorable mechanism.

\section{Limiting dissociative mechanism:}

Both reaction pathways start at $\left[\mathrm{Zn}(\mathrm{HCN})_{6} \cdot \mathrm{HCN}\right]^{2+}$ as reactant state. As depicted in Figure 1, the reactant has one hydrogen cyanide molecule in the second coordination sphere bound by a single hydrogen bond of $1.90 \AA$ to one of the hydrogen cyanide molecules in the first coordination sphere of $C_{4}$ symmetric $\left[\mathrm{Zn}(\mathrm{HCN})_{6} \cdot \mathrm{HCN}\right]^{2+}$. Detaching one of the coordinated hydrogen cyanide molecules leads to the transition state for the limiting dissociative mechanism (see Figure 2). In the transition state the HCN$\mathrm{Zn}^{2+}$ interaction is broken and a hydrogen bond with one of the coordinated HCN in the first coordination shell is formed, leading to a five-coordinate $\mathrm{Zn}^{2+}$ ion as intermediate. In this structure, the leaving HCN molecule becomes part of the second coordination sphere and forms a hydrogen bond with a $\mathrm{HCN}$ molecule in the first coordination sphere of 1.85 $\AA$ and in parallel the hydrogen bonded $\mathrm{HCN}$ of the first coordination sphere is bound more tightly (see Figure 3). The distance between the leaving HCN molecule and the central metal atom is 4.04 and $6.14 \AA$ in the transition and intermediate states, respectively. On the other hand, the hydrogen bond distance is 3.62 and $1.85 \AA$, respectively. The coordination sphere changes from an octahedral, via a distorted trigonal-bipyramidal in the transition state, to a symmetric trigonal-bipyramidal structure for the five-coordinate intermediate. 


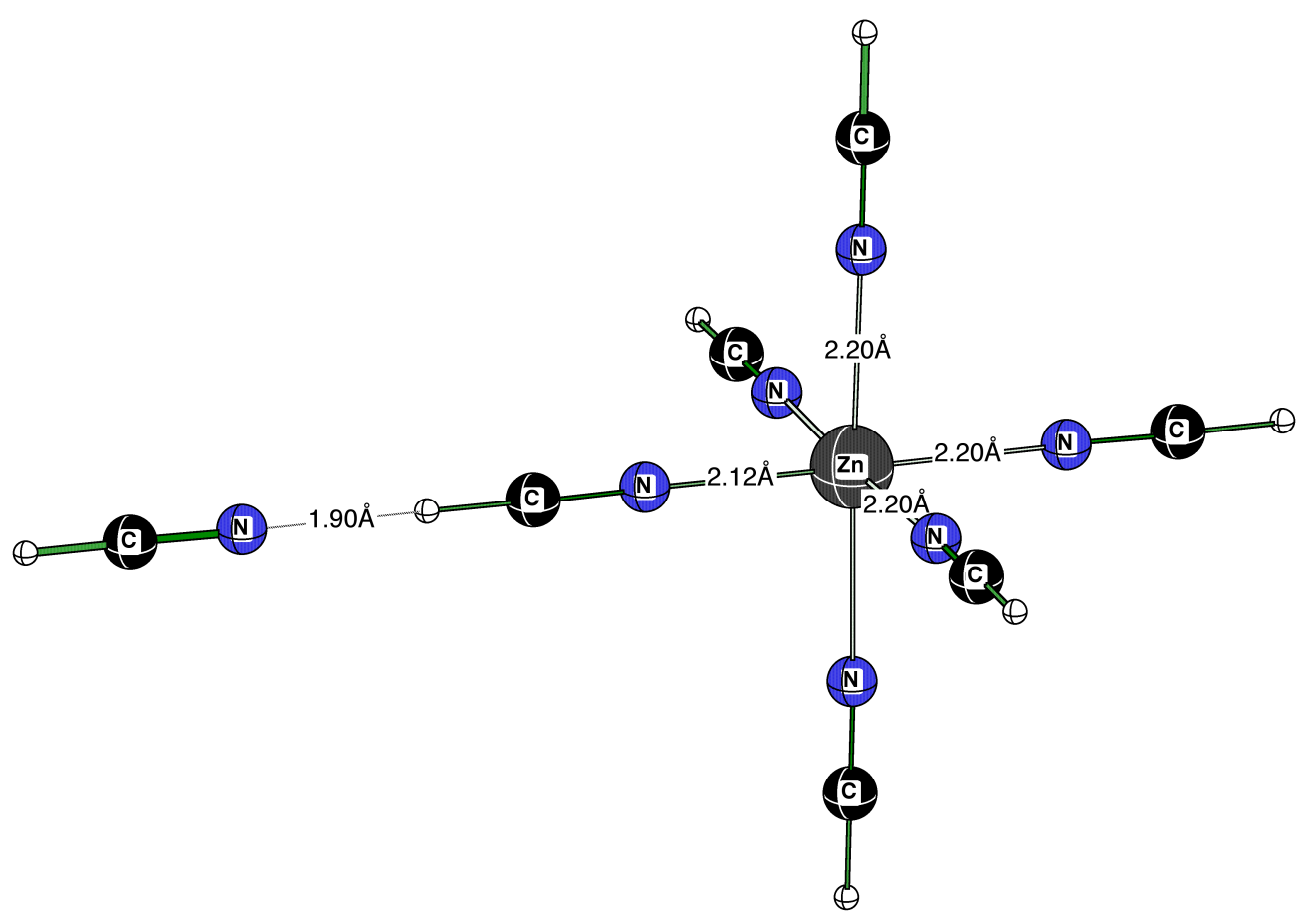

Figure 1. Calculated structure (RB3LYP/6-311+G**) of the reactant state $\left[\mathrm{Zn}(\mathrm{HCN})_{6} \cdot \mathrm{HCN}\right]^{2+}$.

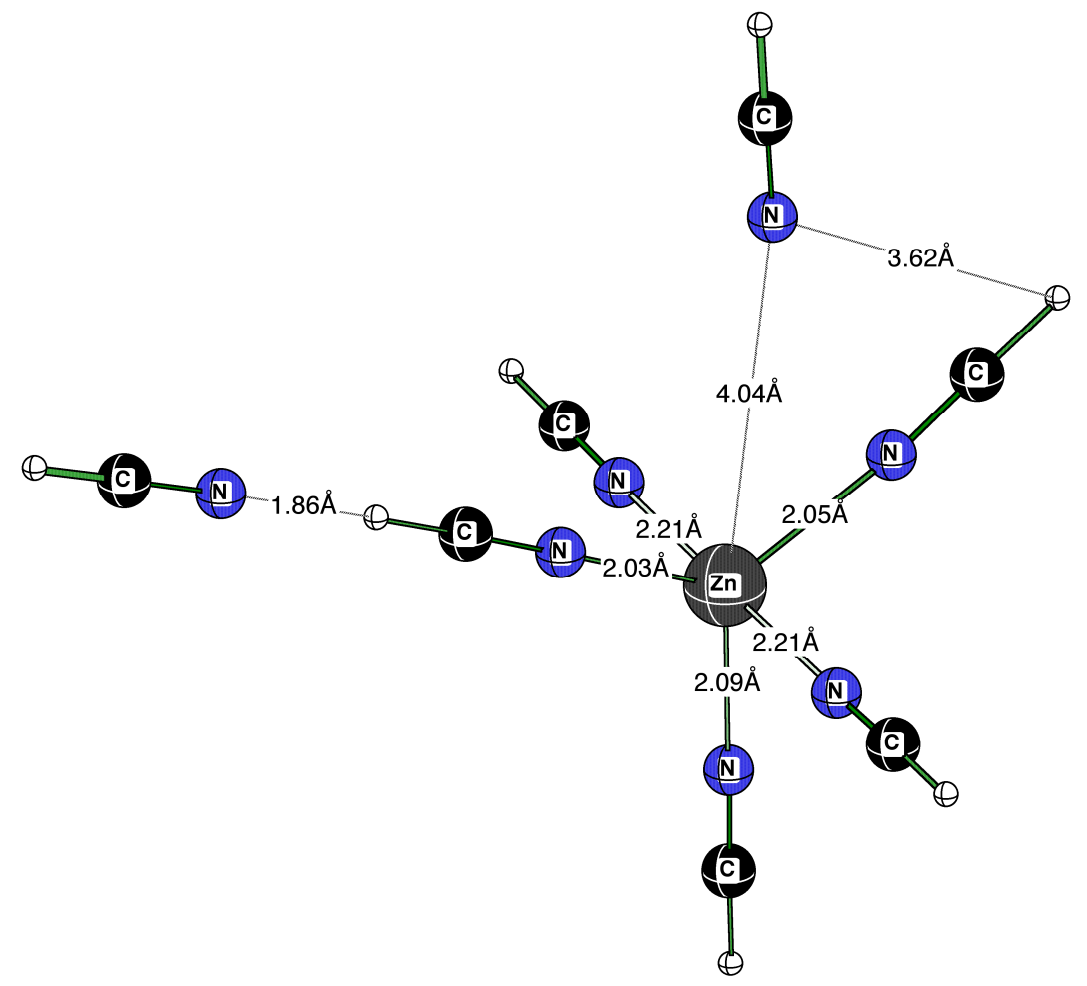

Figure 2. Calculated structure (RB3LYP/6-311+G**) of the transition state $\left[\mathrm{Zn}(\mathrm{HCN})_{5} \cdot 2 \mathrm{HCN}\right]^{2+\ddagger}$. 


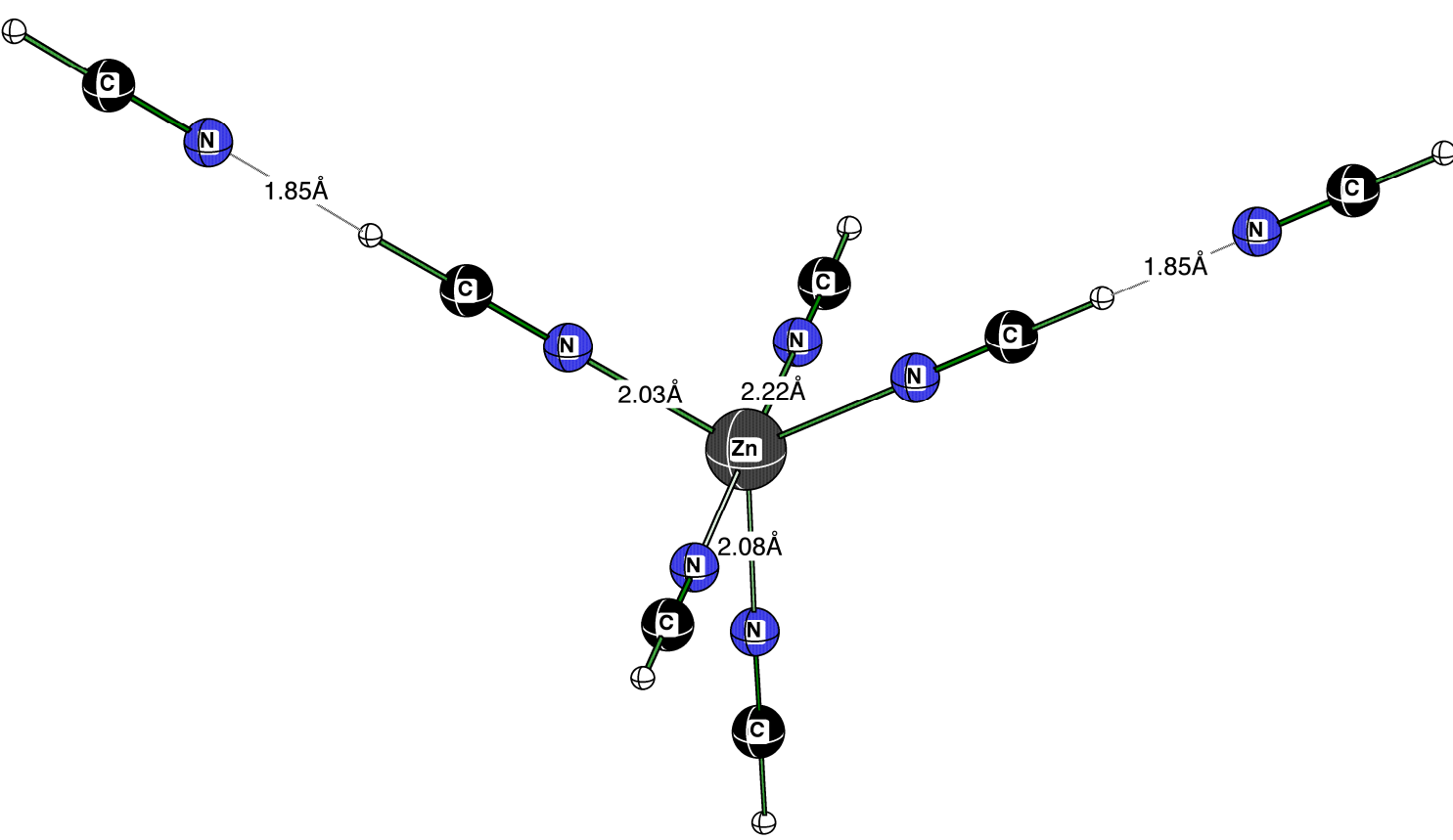

Figure 3. Calculated structure (RB3LYP/6-311+G**) of the five-coordinate intermediate $\left[\mathrm{Zn}(\mathrm{HCN})_{5} \cdot 2 \mathrm{HCN}\right]^{2+}$.

\section{Associative interchange mechanism:}

The $C_{2}$ symmetric transition state of the associative interchange $\left(\mathrm{I}_{\mathrm{a}}\right)$ mechanism contains two weakly coordination $(2.41 \AA)$ exchanging hydrogen cyanide molecules (see Figure 4) [26]. Starting from $\left[\mathrm{Zn}(\mathrm{HCN})_{6} \cdot \mathrm{HCN}\right]^{2+}$, the second sphere hydrogen bonded $\mathrm{HCN}$ molecule moves into the first coordination sphere and weakens the $\mathrm{Zn}-\mathrm{NCH}$ bond of the cis standing HCN molecule, which is released during the exchange process. The $\mathrm{Zn}-\mathrm{N}$ bond lengths of the reactant state are significant shorter than in the case of the transition state of the $I_{a}$ mechanism (see Figures 1 and 4). The first coordination sphere changes from an octahedral structure in the reactant to a distorted pentagonal-bipyramidal structure in the transition state. The entering HCN molecule has come significantly close to the $\mathrm{Zn}$ (II) center in the transition state for the mechanism to be classified as associative interchange $\left(\mathrm{I}_{\mathrm{a}}\right)$. 


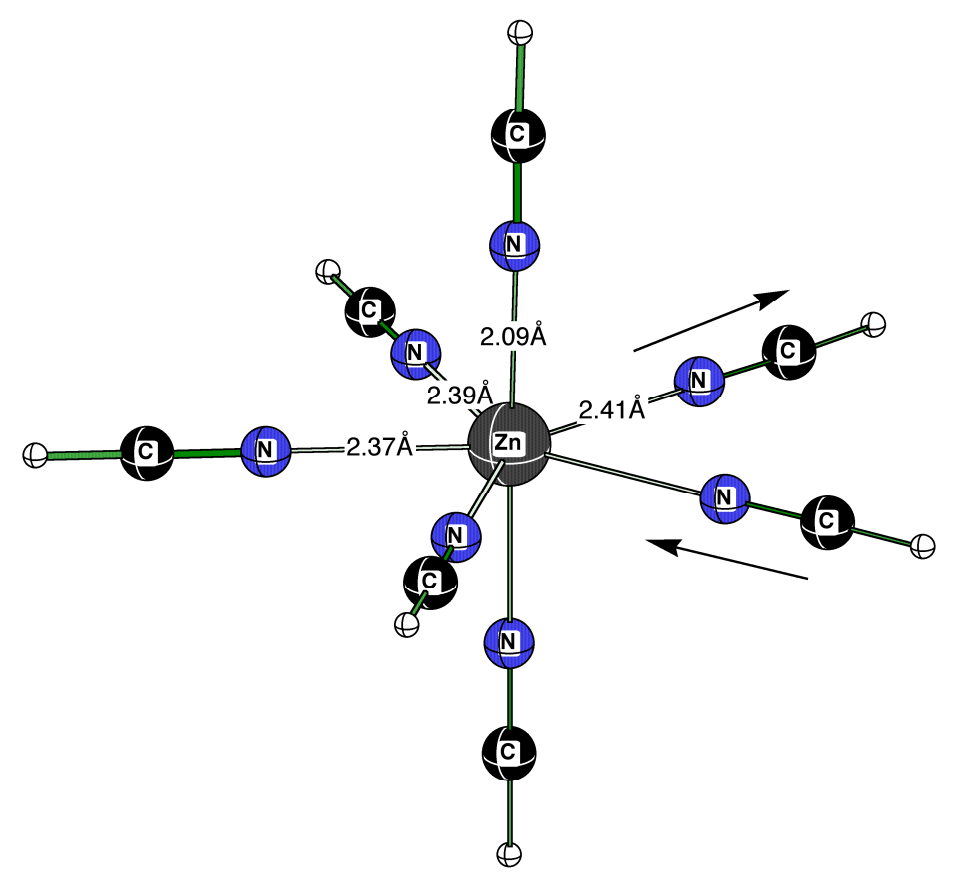

Figure 4. Calculated structure (B3LYP/6-311+G**) of the transition state $\left[\mathrm{Zn}(\mathrm{HCN})_{7}\right]^{2+\ddagger}$.

\section{Attribution of the mechanism:}

A comparison of the activation barriers shows that the limiting dissociative pathway is clearly favored since lies $8.9 \mathrm{kcal} \mathrm{mol}^{-1}$ lower in energy than the transition state of the associative interchange mechanism (see Scheme 1). We attribute the difference in stability between the two transition states to bond weakening of the five equatorial HCN ligands in $\left[\mathrm{Zn}(\mathrm{HCN})_{7}\right]^{2+\ddagger}$ which are elongated by $0.2 \AA$ with respect to the ground state $\left[\mathrm{Zn}(\mathrm{HCN})_{6} \cdot \mathrm{HCN}\right]^{2+}$. Whereas the equatorial ligands undergo only smaller changes in the limiting dissociative transition state, three of the five coordinated HCN ligands in $\left[\mathrm{Zn}(\mathrm{HCN})_{5} \cdot 2 \mathrm{HCN}\right]^{2+\ddagger}$ are bound even more tightly than in the ground state. The fivecoordinate intermediate of the limiting dissociative mechanism, $\left[\mathrm{Zn}(\mathrm{HCN})_{5} \cdot 2 \mathrm{HCN}\right]^{2+}$, is as stable as the ground state reactant complex $\left[\mathrm{Zn}(\mathrm{HCN})_{6} \cdot \mathrm{HCN}\right]^{2+}$. 


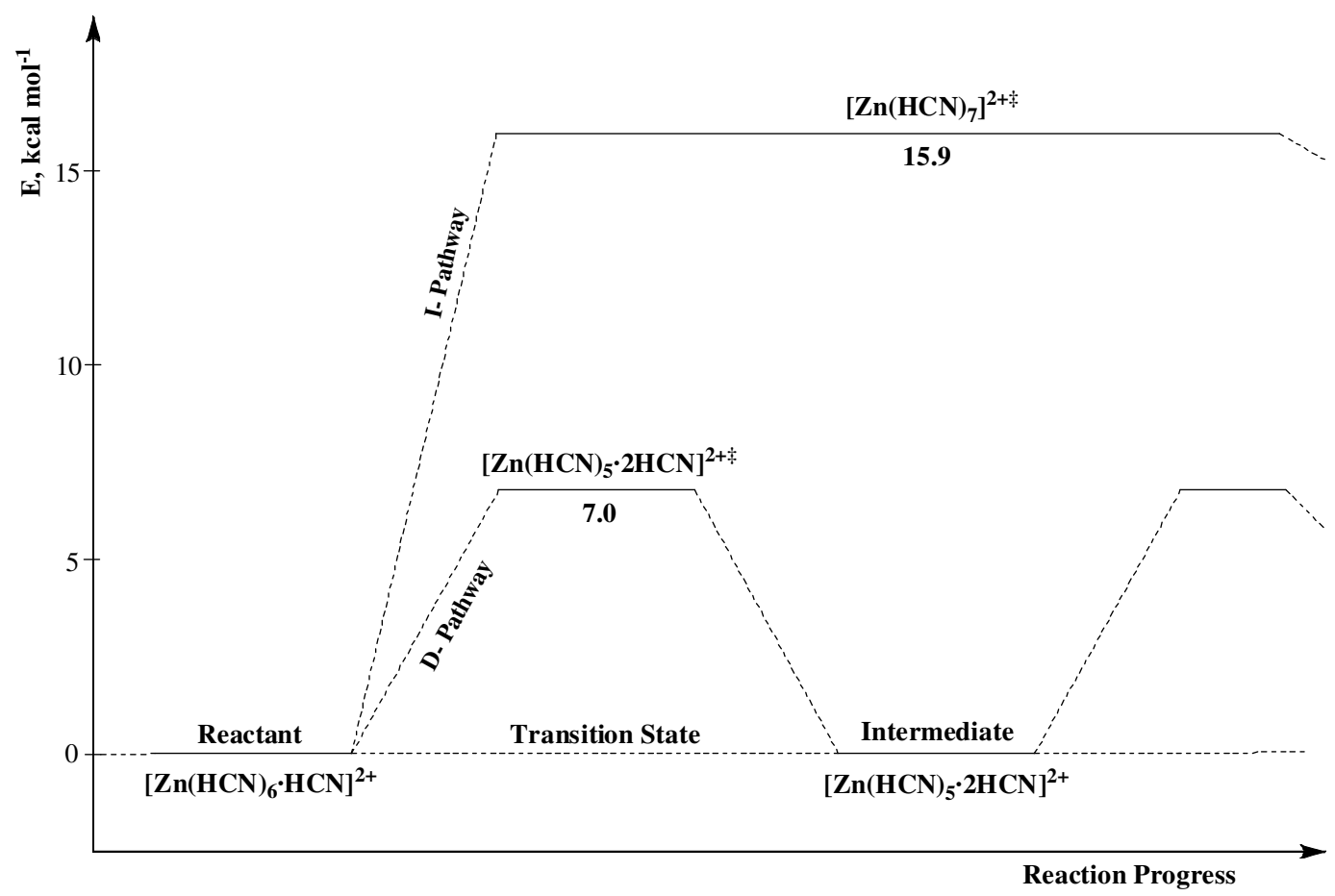

Scheme 1. Calculated (B3LYP/6-311+G**) energy profile for $\mathrm{HCN}$ exchange on $\left[\mathrm{Zn}(\mathrm{HCN})_{6}\right]^{3+}$ according to limiting dissociative (D) and associative interchange $\left(\mathrm{I}_{\mathrm{a}}\right)$ reaction pathways.

As mentioned above, the bond lengths in the transition state $\left[\mathrm{Zn}(\mathrm{HCN})_{7}\right]^{2+\ddagger}$ are clearly longer and the metal-ligand interactions are therefore weaker than in the case of $\left[\mathrm{Zn}(\mathrm{HCN})_{5} \cdot 2 \mathrm{HCN}\right]^{2+\ddagger}$ (see Table 1). Rotzinger[14,27] suggested as a quantum-chemical descriptor for the activation volume that the sign of the change of the sum of all M-ligand bond lengths $\left(\Delta \sum\right)$ during the activation process should agree with the sign of $\Delta V^{\ddagger}$. In accordance with the expected trend, the calculated change in the $\mathrm{Zn}-\mathrm{N}$ bond lengths during the exchange reaction $\left(\Delta \sum\right)$ were found to be positive for the limiting dissociative mechanism and negative for the associative interchange mechanism (see Table 1). In addition, $\sum \mathrm{r}_{3}$ increases significantly on going from the transition state, $\left[\mathrm{Zn}(\mathrm{HCN})_{5} \cdot 2 \mathrm{HCN}\right]^{2+\ddagger}$, to the five-coordinate intermediate, $\left[\mathrm{Zn}(\mathrm{HCN})_{5} \cdot 2 \mathrm{HCN}\right]^{2+}$, of the limiting dissociative mechanism, again in line with the expected trend for such a mechanism. 
Table 1. Selected structural parameters for $\mathrm{HCN}$ exchange on $\left[\mathrm{Zn}(\mathrm{HCN})_{6} \cdot \mathrm{HCN}\right]^{2+}$.

\begin{tabular}{|c|c|c|c|c|}
\hline $\mathrm{r}_{1}(\mathrm{Zn}-\mathrm{N}) / \AA$ & $\mathrm{r}_{2}(\mathrm{Zn} \cdots \mathrm{N}) / \AA$ & & & \\
\hline $\begin{array}{c}\text { First } \\
\text { coordination } \\
\text { sphere }\end{array}$ & $\begin{array}{c}\text { Second } \\
\text { coordination } \\
\text { sphere }\end{array}$ & $\begin{array}{c}\mathrm{r}(\mathrm{N} \cdots \mathrm{HCN}-\mathrm{Zn}), \\
/ \AA\end{array}$ & $\sum \mathrm{r}_{3}=\sum \mathrm{r}_{1}+\sum \mathrm{r}_{2} / \AA$ & $\Delta \sum\left(\sum \mathrm{r}_{3}{ }^{\ddagger}-\sum \mathrm{r}_{3}{ }^{*}\right) / \AA$ \\
\hline \multicolumn{5}{|c|}{$\left[\mathrm{Zn}(\mathrm{HCN})_{6}\right]^{2+} \cdot \mathrm{HCN},\left(C_{4}\right)$} \\
\hline $\begin{array}{l}2.20,2.20,2.20, \\
2.20,2.20 .2 .12\end{array}$ & 6.26 & 1.90 & $19.38^{*}$ & --- \\
\hline \multicolumn{5}{|c|}{$\left[\mathrm{Zn}(\mathrm{HCN})_{5} \cdot 2 \mathrm{HCN}\right]^{2+\sharp},\left(C_{l}\right)$} \\
\hline $\begin{array}{c}2.03,2.21,2.09 \\
2.05,2.21\end{array}$ & $4.04,6.14$ & $1.86,3.62$ & 20.79 & +1.41 \\
\hline \multicolumn{5}{|c|}{$\left[\mathrm{Zn}(\mathrm{HCN})_{5} \cdot 2 \mathrm{HCN}\right]^{2+},\left(C_{l}\right)$} \\
\hline $\begin{array}{c}2.03,2.03,2.08, \\
2.22 .2 .22\end{array}$ & $6.14,6.14$ & $1.85,1.85$ & 22.86 & --- \\
\hline \multicolumn{5}{|c|}{$\left[\mathrm{Zn}(\mathrm{HCN})_{7}\right]^{2+\ddagger},\left(C_{2}\right)$} \\
\hline $2.41,2.39,2.37$ & & & & \\
\hline $\begin{array}{c}2.39,2.09,2.09 \\
2.41\end{array}$ & & --- & 16.15 & -3.38 \\
\hline
\end{tabular}

The overall mechanistic findings demonstrate that as in the case of $\mathrm{Li}^{+},[17,18] \mathrm{Be}^{2+},[19]$ and $\mathrm{Al}^{3+},[20,21]$ water and $\mathrm{HCN}$ exhibit the same type of exchange mechanism such that $\mathrm{HCN}$ can be considered to be a water like solvent.

Besides using $\mathrm{HCN}$ as a water-like solvent for quantum chemical studies, hydrogen cyanide is employed as a simplified working model for acetonitrile. To the best of our knowledge there is no $\left[\mathrm{Zn}(\mathrm{HCN})_{6}\right]^{2+}$ structure investigated by $\mathrm{x}$-ray analysis up to know, and we therefore decided to compare the calculated structure of $\left[\mathrm{Zn}(\mathrm{HCN})_{6}\right]^{2+}$ with that of $\left[\mathrm{Zn}\left(\mathrm{CH}_{3} \mathrm{CN}\right)_{6}\right]^{2+}[2]$ and $\left[\mathrm{Zn}(\mathrm{PhCN})_{6}\right]^{2+}[2]$ as well as $\left[\mathrm{Zn}(\mathrm{NC}-\mathrm{CN})_{6}\right]^{2+}[28]$. As 
expected we find satisfactory agreement between the experimental determined and calculated structures (Table 2).

Table 2. Comparison of measured and calculated (B3LYP/6-311+G**) Zn $\cdots \mathrm{NCH}$ bond lengths.

\begin{tabular}{cccc}
\hline Complex & $\mathrm{r}(\mathrm{Zn}-\mathrm{N}) / \AA$ (x-ray) & $\mathrm{r}(\mathrm{Zn}-\mathrm{N}) / \AA(\mathrm{DFT})$ & Point group \\
\hline$\left[\mathrm{Zn}(\mathrm{HCN})_{6}\right]^{2+}$ & - & 2.19 & $O_{h}$ \\
{$\left[\mathrm{Zn}\left(\mathrm{CH}_{3} \mathrm{CN}\right)_{6}\right]^{2+}$} & $2.134[2]$ & 2.18 & $C_{l}$ \\
{$\left[\mathrm{Zn}(\mathrm{PhCN})_{6}\right]^{2+}$} & $2.108-2.157[2]$ & 2.18 & $T_{h}$ \\
{$\left[\mathrm{Zn}(\mathrm{NC}-\mathrm{CN})_{6}\right]^{2+}$} & $2.134[28]$ & 2.19 & $O_{h}$ \\
\hline
\end{tabular}

DFT: B3LYP/6-311+G**

During the investigation of $\left[\mathrm{Al}(\mathrm{HCN})_{6} \cdot(\mathrm{HCN})\right]^{3+}$, we found that the length of the hydrogen bond between $\mathrm{HCN}$ in the first and second coordination spheres depends mainly on the charge of the central metal ion. A comparison between $\left[\mathrm{Be}(\mathrm{HCN})_{4} \cdot(\mathrm{HCN})\right]^{2+}$ and $\left[\mathrm{Zn}(\mathrm{HCN})_{6} \cdot(\mathrm{HCN})\right]^{2+}$ nicely shows that the $\mathrm{HCN} \cdots \mathrm{HCN}$ hydrogen bond lengths are in the expected range between 1.7 and $1.9 \AA$ (see Figure 5). The slight elongation is understandable since the $\mathrm{Zn}^{2+}$ cation is six-coordinate and can compensate the positive charge better than the four-coordinate $\mathrm{Be}^{2+}$ cation. 


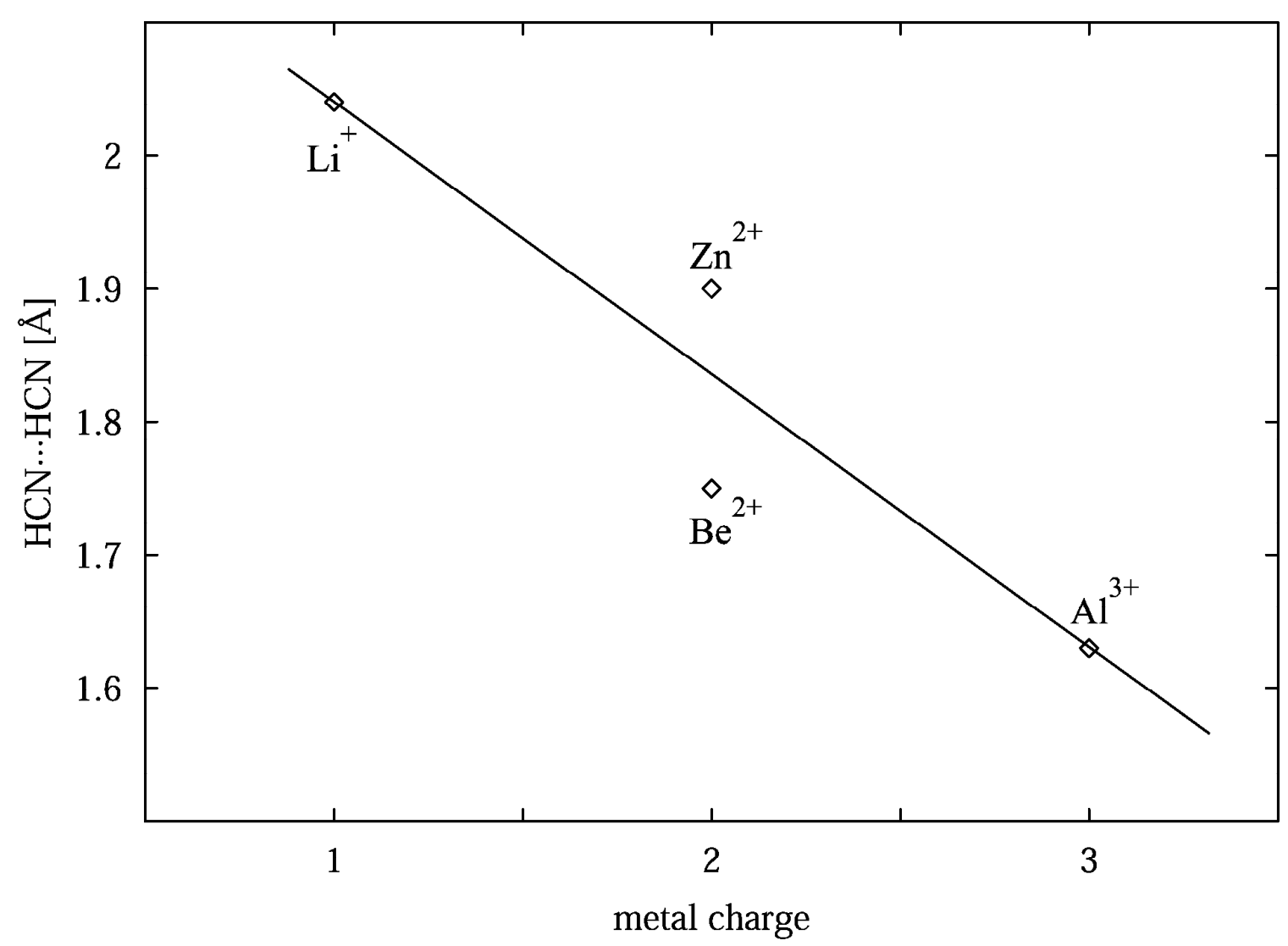

Figure 5. Plot of calculated hydrogen bond lengths for $\mathrm{r}(\mathrm{HCN} \cdots \mathrm{NCH})$ in $\left[\mathrm{M}(\mathrm{HCN})_{\mathrm{m}} \cdot(\mathrm{HCN})\right]^{\mathrm{n}+}, \mathrm{M}=\mathrm{Li}(\mathrm{m}=4, \mathrm{n}=1),[22] \mathrm{Be}(\mathrm{m}=4, \mathrm{n}=2),[23 \mathrm{a}] \mathrm{Zn}(\mathrm{m}=6, \mathrm{n}=$ 2) and $\mathrm{Al}(\mathrm{m}=6, \mathrm{n}=3)[21]$ complexes versus the charge on the metal ion.

A comparison of the dissociative $\mathrm{HCN}$ exchange on $\left[\mathrm{Zn}(\mathrm{HCN})_{6}\right]^{2+}$ and $\left[\mathrm{Al}(\mathrm{HCN})_{6}\right]^{3+}[21]$ shows that the sum of the metal-nitrogen bond lengths $\left(\sum(\mathrm{M}-\mathrm{NCH})\right)$ as a quantum chemical descriptor for $\Delta V^{\ddagger}$ is shorter in the case of $\mathrm{M}=\mathrm{Al}^{3+}$ since the attraction depends on the charge of the metal ion. The activation barriers for $\left[\mathrm{Zn}(\mathrm{HCN})_{6}\right]^{2+}$ and $\left[\mathrm{Al}(\mathrm{HCN})_{6}\right]^{3+}[21]$ were found to be 7 and $23.4 \mathrm{kcal} \mathrm{mol}^{-1}$, respectively, and the intermediate in the case of $\mathrm{Zn}^{2+}$ is at zero energy relative to the reactant state, but at 12.1 $\mathrm{kcal} \mathrm{mol}^{-1}$ for $\left[\mathrm{Al}(\mathrm{HCN})_{6}\right]^{3+}[21]$. The activation barriers show that the larger zinc ion $(\mathrm{r}=$ $0.74 \AA$ ) has a better ability to form the six-coordinate structure than the much smaller $\mathrm{Al}^{3+}$. The significantly smaller activation barrier for $\left[\mathrm{Zn}(\mathrm{HCN})_{6}\right]^{2+}$ can easily be attributed to the lower charge as compared to $\left[\mathrm{Al}(\mathrm{HCN})_{6}\right]^{3+}$. 


\section{Conclusion}

The computed structural parameters and activation energies for hydrogen cyanide exchange on $\left[\mathrm{Zn}(\mathrm{HCN})_{6}\right]^{2+}$ show that the limiting dissociative (D) pathway is more favorable than the alternative associative interchange $\left(I_{a}\right)$ mechanism. A comparison of the transition state for the limiting $\mathrm{D}$ and associative interchange $\left(\mathrm{I}_{\mathrm{a}}\right)$ mechanisms, favors the dissociative transition state by $8.9 \mathrm{kcal} \mathrm{mol}^{-1}$. This study clearly outlines how important the consideration of transition states and intermediates in mechanistic studies are.

\section{Acknowledgements}

The authors gratefully acknowledge financial support from the Deutsche Forschungsgemeinschaft. We would like to thank Prof. Tim Clark for hosting this work at the CCC and the Regionales Rechenzentrum Erlangen (RRZE) for a generous allotment of computer time. BMA thanks the Higher Council for Science and Technology in Jordan, and Al-Balqa Applied University for their support. 


\section{References}

[1] (a) R. J. P. Williams, Biometals 2007, 20, 107. (b) R. J. P. Williams, Chem. Commun., 2003, 1109. (c) T. Dudev, C. Lim, Chem. Rev. 2003, 103, 773. (d) J. M. Berg, H. A. Godwin, Annu. Rev. Biophys. Biomol. Struct. 1997, 26, 357.

[2] Ö. N. Akkuş, A. Decken, C. Knapp, J. Passmore, J. Chem. Crystallography 2006, 36 321.

[3] (a) Y. Marcus, Chem. Rev. 1988, 88, 1475. b) I. L. Alberts, K. Nadassy, S. J. Wodak, Protein Sci. 1988, 7, 1700.

[4] (a)V. M. Rayon, H. Valdes, N. Diaz, D. Suarez, J. Chem. Theory Comput. 2008, 4, 243.(b) J. Weston, Chem. Rev. 2005, 105, 2151. (c) H. Vahrenkamp, Dalton Trans. 2007, 4751.

[5] (a) B. O. Jahn, W. A. Eger, E. Anders, J. Org. Chem. 2008, 73, 8265. (b) U. Siemeling, Th. Klemann, C Bruhn, B. Neumüller, K. Dehnicke Z. Anorg. Allg. Chem. 2008, 634, 895. (c) J. Elflein, F. Platzmann, N. Burzlaff, Europ. J. Inorg. Chem. 2007, 5173. (d) H. Ge, H. Vahrenkamp, Z. Anorg. Allg. Chem. 2007, 633, 51. (e) S. Schenk, J. Notni, U. Köhn, K. Wermann, E. Anders, Dalton Trans. 2006, 4191. (e) M. M. Ibrahim, H. Vahrenkamp, Z. Anorg. Allg. Chem. 2006, 632, 1083. (f) M. Mauksch, M. Bräuer, J. Weston, E. Anders ChemBioChem 2001, 2, 190.

[6] (a) J. Notni, S. Schenk, H. Görls, H. Breitzke, E. Anders, Inorg. Chem. 2008, 47, 1382. (b) J. A. M. Calvo, H. Vahrenkamp Z. Anorg. Allg. Chem. 2006, 1776.

(b) S. G. Zhang, C. Hou, Acta Crystall. Sec. E 2008, E64, m1131.

[7] (a) C-H. Yu, Acta Crystall. Sec. E 2008, E64, m1158. (b) (b) O. Schneider, E. Gerstner, F. Weller, K. Dehnicke Z. Anorg. Allg. Chem. 1999, 625, 1101.

[8] (a) G. Schürer, T. Clark, R. van Eldik "The reaction mechanisms of zinc enzymes" in Z. Rappoport, I. Marek, The Chemistry of Organozinc Compounds, Chap. 1, Part 1, John Wiley \& Sons Ltd, England, (2006). (b) H. Vahrenkamp, Acc. Chem. Res. 1999, 32, 589.

[9] H. Erras-Hanauer, T. Clark, R. van Eldik, Coord. Chem. Rev. 2003, 238-239, 233.

[10] L. Helm, A. E. Merbach, Coord. Chem. Rev. 1999, 187, 151.

[11] R. van Eldik, Studies in Inorganic Chemistry, Inorganic High Pressure Chemistry, Elsevier, Amsterdam, (1986). 
[12] M. Hartmann, T. Clark, R. van Eldik, J. Mol. Model. 1996, 2, 354.

[13] M. Hartmann, T. Clark, R. van Eldik, J. Am. Chem. Soc. 1997, 119, 5867.

[14] F. P. Rotzinger, J. Am. Chem. Soc. 1996, 118, 6760.

[15] Y. Wasada-Tsutsui, H. Wasada, S. Funahashi, Bull. Chem. Soc. Jpn. 2003, 76, 1713.

[16] (a) G. Jander, W. Klemm, Die Chemie in Wasserähnlichen Lösungsmitteln, Springer-Verlag, Berlin, 1949. (b) J. Jander, C. Lafrenz, Wasserähnliche Lösungsmittel, Springer-Verlag, Berlin, 1968. (c) J. Jander, G. Tuerk, Chem. Ber. 1962, 95, 881. (d) J. Jander, G. Tuerk, Chem. Ber. 1962, 95, 2314. (e) J. Jander, G. Tuerk, Chem. Ber. 1965, 98, 894. (f) I. Bako, T. Megyes, G. Palinkas, Chem. Phys. 2005, 316, 235.

[17] R. Puchta, M. Galle, N. van Eikema Hommes, E. Pasgreta, R. van Eldik, Inorg. Chem. 2004, 43, 8227.

[18] E. Pasgreta, R. Puchta, A. Zahl, R. van Eldik, Eur. J. Inorg. Chem. 2007, 1815.

[19] R. Puchta, and R. van Eldik, Helv. Chim. Acta 2008, 91, 1063.

[20] H. Hanauer, R. Puchta, T. Clark, R. van Eldik, Inorg. Chem. 2007, 46, 1112.

[21] R. Puchta, B. M. Alzoubi, R. van Eldik, Z. Anorg. Allg. Chem. 2009, 635, 434.

[22] E. Pasgreta, R. Puchta, M. Galle, N. van Eikema Hommes, A. Zahl, R. van Eldik, ChemPhysChem 2007, 8, 1315.

[23] (a) R. Puchta, N. J. R. van Eikema Hommes, R. van Eldik, Helv. Chim. Acta 2005, 88, 911. (b) R. Puchta, R. van Eldik, Z. Anorg. Allg. Chem. 2008, 634, 735. (c) R. Puchta, R. van Eldik, Z. Anorg. Allg. Chem. 2008, 634, 1915.

[24] a) P. J. Stevens, F. J. Devlin, C. F. Chablowski, M. J. Frisch, J. Phys. Chem. 1994, 98, 11623. b) A. D. Becke, J. Chem. Phys. 1993, 98, 5648. c) C. Lee, W. Yang, R. G. Parr, Phys. Rev. 1988, B 37, 785.(d) The performence of this level and this approach is well documented see e.g. R. Puchta, E. Pasgreta, R. van Eldik, Adv. Inorg. Chem. 2009, $61,521-571$.

[25] M. J. Frisch, G. W. Trucks, H. B. Schlegel, G. E. Scuseria, M. A. Robb, J. R. Cheeseman, J. A. Montgomery, Jr., T. Vreven, K. N. Kudin, J. C. Burant, J. M. Millam, S. S. Iyengar, J. Tomasi, V. Barone, B. Mennucci, M. Cossi, G. Scalmani, N. Rega, G. A. Petersson, H. Nakatsuji, M. Hada, M. Ehara, K. Toyota, R. Fukuda, J. Hasegawa, M. Ishida, T. Nakajima, Y. Honda, O. Kitao, H. Nakai, M. Klene, X. Li, J. E. Knox, H. P. 
Hratchian, J. B. Cross, V. Bakken, C. Adamo, J. Jaramillo, R. Gomperts, R. E. Stratmann, O. Yazyev, A. J. Austin, R. Cammi, C. Pomelli, J. W. Ochterski, P. Y. Ayala, K. Morokuma, G. A. Voth, P. Salvador, J. J. Dannenberg, V. G. Zakrzewski, S. Dapprich, A. D. Daniels, M. C. Strain, O. Farkas, D. K. Malick, A. D. Rabuck, K. Raghavachari, J. B. Foresman, J. V. Ortiz, Q. Cui, A. G. Baboul, S. Clifford, J. Cioslowski, B. B. Stefanov, G. Liu, A. Liashenko, P. Piskorz, I. Komaromi, R. L. Martin, D. J. Fox, T. Keith, M. A. Al-Laham, C. Y. Peng, A. Nanayakkara, M. Challacombe, P. M. W. Gill, B. Johnson, W. Chen, M. W. Wong, C. Gonzalez, J. A. Pople, Gaussian 03, Revision B.03, Gaussian Inc., Wallingford, CT, 2004.

[26] The obvious $D_{5 h}$-structure is a higher order saddle point. (NImag:2)

[27] F. P. Rotzinger, J. Am. Chem. Soc. 1997, 119, 5230.

[28] J. Beck, M. Zink, Z. Anorg. Allg. Chem. 2009, 635, 687. 